\title{
МІКРОНАВЧАННЯ ІК-ТЕХНОЛОГІЙ ПЕДАГОГІВ В УМОВАХ ОНЛАЙНОВОГО МАРАФОНУ ЯК ПАРАДИГМА ЦИФРОВОЇ ТРАНСФОРМАЦІЇ ОСВІТИ
}

https://doi.org/10.37472/2707-305X-2021-3-1-10-1

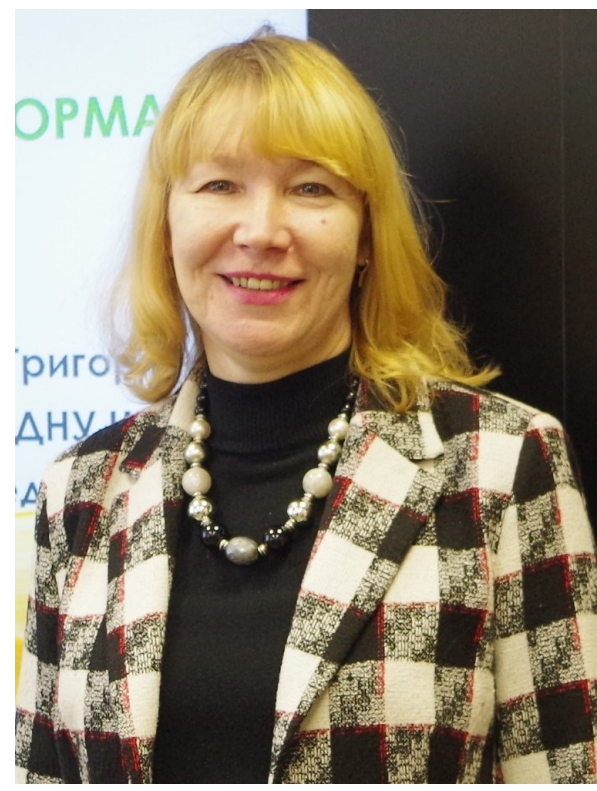

ЛИТВИНОВА

\section{Світлана Григорівна}

доктор педагогічних наук, старший науковий співробітник, заступник директора з наукової роботи Iнституту інформаційних технологій і засобів навчання Начіональної академії педагогічних наук України, м. Київ, Україна

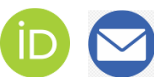

Анотація. У статmі визначено й описано складники цифрової трансформації освіти (дистаниійне навчання, відеоконферениії, онлайнове навчання, імерсивні технології, Smart класи, адаптивне навчання, штучний інтелект і чатботи); обгрунтовано процес упровадження мікронавчання як зростаючої необхідності в короткотривалому індивідуальному навчанні вчителів IK-технологій. Описано мету Дорожньої карти «Європейський підхід до мікрокредитів для навчання впродовж життя та прачевлаштування», що корелює з широкомасштабним упровадженням технології мікронавчання. Проаналізовано основні напрями наукових досліджень і враховано їх результати у розробленні програми онлайнового марафону. Визначено основні принципи впровадження технології мікронавчання, обгрунтовано переваги, недоліки та визначено основні характеристики технології мікронавчання (форма навчання, тривалість навчання, подання змісту, види контенту, фрагментація контенту, форма отримання контенту, цільова група, роль учасників, фокусування навчання). Обгрунтовано процедурну модель організаціі мікронавчання в умовах онлайнового марафону. Описано основні види мікрозавдань та сервісів для їх виконання. Описано результати онлайнового марафону за участі 1200 педагогів, які підтвердили есективність розвитку IК-компетентності педагогічних прачівників в умовах неформального навчання за технологією мікронавчання.

Ключові слова: мікронавчання; ІК-технології; педагоги; онлайнове навчання; марафон; цифрова трансформачії освіти.

Цифрова трансформація освіти є сучасним етапом інформатизації освіти і результатом довготривалого карантину, спричиненого широкомасштабною пандемією COVID-19. Вона означає поліпшення основних процесів організації освіти за рахунок використання великих даних (Bigdata) і цифрових технологій (Digital Technology), зокрема дистанційного навчання, відеоконференцій та онлайнового навчання, використання імерсивних технологій, Smart класів, адаптивного навчання, штучного інтелекту, чатботів, для ефективного задоволення вимог і потреб здобувачів освіти (рис. 1).

Роль педагогічного працівника у процесі трансформації освіти є ключовою і вимагає від нього відповідного рівня IKкомпетентності та умінь орієнтуватися в сучасних інформаційних технологіях. 3 огляду на те, що цифрова компетентність педагога має підтримуватися на належному рівні і постійно підвищуватися, виникає потреба в започаткуванні нових форм навчання практикуючих педагогів у рамках неформальної освіти, а саме мікронавчання.

У проєкті Дорожньої карти «Європейський підхід до мікрокредитів для навчання впродовж життя та працевлаштування» зазначено, що залежно від того, як економіка оговтається від 


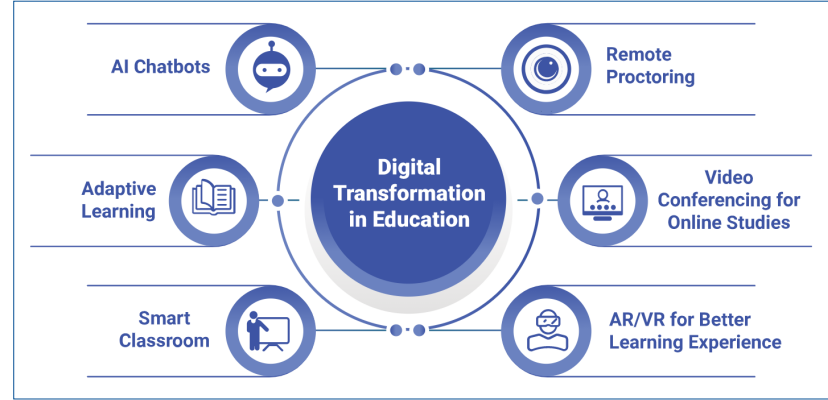

Рис. 1. Складники цифрової трансформації в освіті (LeewayHertz, 2021)

кризи COVID-19, очікується зростання попиту на короткотривалі форми навчання та їх визнання й перевірку. Цифрова трансформація вимагає від людей навчання або перекваліфікації для успішного переходу з однієї роботи або економічного сектору в інший, а також для отримання доступу до подальших досліджень, і, як наслідок, зростатиме потреба в короткотривалому та індивідуальному навчанні» (European Commission, 2021).

Ураховуючи дані Statistic Brain, що вказують на зменшення тривалості концентрації уваги людини за останні 15 років з 12 до 8,25 секунд (Kokoulina, 2020), мікронавчання можна розглядати як ефективну форму навчання впродовж життя, зокрема практикуючих педагогів закладів освіти.

Питання мікронавчання досліджувалося вченими за різними напрямами. Особливо затребуваною ця технологія $€$ на курсах підвищення професійної майстерності педагогів. У слухачів з'являється можливість з цеглинок-мікрозанять створювати власну освітню траєкторію вдосконалення професійних компетентностей (Монахова, Монахов \& Прончев, 2020).

У ході дослідження вченого A.I.Sen (2009) $з$ Університету Хаджеттепе вчителі фізики зазначили, що така практика навчання істотно відрізняється від інших форм, і вони отримали значний позитивний досвід, який полягав у покроковому розвитку навичок.

На важливості забезпечення процесу навчання якісною наочністю наголошував Т. Hug (2010). Одним із варіантів розв'язання цієї проблеми він зазначив візуалізацію кожного етапу (кроку) у процесі мікронавчання.

Учені В.Є. Величко і О.Г. Федоренко (2020), аналізуючи статистичні дані щодо тривалості навчальної діяльності, дійшли висновку, що навчальна сесія під керівництвом наставника може перевищувати 20 хвилин, а під час самостійного вивчення навчального матеріалу колива- тися від 5 до 10 хвилин. Останнє повністю відповідає технології мікронавчання.

Учені В.М. Соловйов, С.О. Семеріков, І.О. Теплицький (2009) наголошують, що одним із способів реалізації мікронавчання $€$ мобільне навчання, яке забезпечує мобільність (у сенсі Болонської декларації) в порівнянні з електронним або традиційним навчанням.

У 2020 р. технологія мікронавчання набула нового змісту і стала затребуваною педагогами, зокрема для розвитку ІК-компетентностей. Ми врахували результати дослідження В.Є. Величко і О.Г. Федоренко у процесі проведення онлайнового марафону і замінили відеоуроки онлайновими вебінарами. Акцент учених В.М. Соловйова, С.О. Семерікова, І.О. Теплицького на мобільності дав змогу використати 2 базові сервіси Microsoft Teams i Facebook для організації онлайнового марафону як середовища для навчання і середовища комунікації учасників відповідно. Рекомендації щодо покрокової візуалізації змісту навчання були враховані доповідачами (спікерами) під час проведення онлайнових вебінарів. Відтак необхідним $€$ обгрунтування технології мікронавчання як ефективної онлайнової форми розвитку IK-компетентності практикуючих педагогів в умовах неформального навчання.

Мікронавчання (англ. microlearning) - це підхід до навчання, що передбачає набуття навичок, у процесі яких інформація надається у невеликому обсязі. У наукових працях вчені зазначають, що таке навчання застосовують 3 метою отримання короткого огляду процесу або технології в умовах перегляд відеоуроку (Монахова, Монахов \& Прончев, 2020).

Мікронавчання пов'язане з такими поняттями: неформальне навчання, індивідуальне навчальне середовище, діяльнісний підхід.

Неформальне навчання - процес навчання, не регламентований місцем, строком та формою.

Індивідуальне навчальне середовище сукупність засобів, інструментів, технологій, методів, служб, спільнот, інших інформаційних ресурсів, що використовуються людиною для управління своїм самонавчанням, побудови навчальної траєкторії, стимуляції навчальної активності, розвитку особистісних здатностей, пошуку та обробки інформації, комунікації та співпраці (Олійник \& Половін, 2014).

Діяльнісний підхід - в основу покладено обов'язкове виконання завдань та набуття навичок. 
До переваг мікронавчання з використанням відеоуроку/вебінару можна віднести концентрацію уваги, доступність, мобільність, модульність і гнучкість.

Концентрація уваги. Зосередження уваги на головному - «зрозуміти ідею» розв'язання завдання або використання технології.

Мобільність. Ознайомлення з відеоуроком може відбуватися будь-де та в будь-який час. Проте участь у вебінарі потребує обов'язкової присутності, тому мобільність учасника розглядається як відсутність прив'язки до гаджета або місця проведення.

Доступність. Використання комп'ютерно орієнтованих систем навчання, доступних як 3 мобільного телефону, так і з персонального комп'ютера або ноутбука.

Модульність і гнучкість. Інформація надається користувачеві у вигляді невеликих блоків, кожен з яких можна легко переставити або замінити. Таким чином, навчальна програма стає більш гнучкою.

Недоліки мікронавчання ми вбачаємо в тому, що зазначений підхід не дає змоги вивчати складні теми з численними етапами і завданнями. Іншими словами, ідея мікронавчання полягає в опануванні первинних навичок або компетентностей базового рівня.

До основних характеристик мікронавчання віднесено: форму навчання, тривалість навчання, подання змісту, види контенту, фрагментацію контенту, форму отримання контенту, цільову групу, роль учасників, фокусування навчання (табл. 1).

Табличя 1

Основні характеристики мікронавчання

\begin{tabular}{|c|c|c|}
\hline № & Критерії & Показники \\
\hline 1. & $\begin{array}{l}\text { Форма } \\
\text { навчання }\end{array}$ & Неформальне навчання \\
\hline 2. & $\begin{array}{l}\text { Тривалість } \\
\text { навчання }\end{array}$ & 15-20 хвилин \\
\hline 3. & $\begin{array}{l}\text { Подання } \\
\text { змісту }\end{array}$ & $\begin{array}{l}\text { Мікроконтент як невелика } \\
\text { за обсягом інформація, } \\
\text { зосереджена на одній ідеї, темі, } \\
\text { технології }\end{array}$ \\
\hline 4. & $\begin{array}{l}\text { Види } \\
\text { контенту }\end{array}$ & $\begin{array}{l}\text { Відеофрагменти, онлайн } \\
\text { вебінари }\end{array}$ \\
\hline 5. & $\begin{array}{l}\text { Фрагментація } \\
\text { контенту }\end{array}$ & $\begin{array}{l}\text { Мікроконтент не можна } \\
\text { розділити на більш дрібні } \\
\text { частини без втрати сенсу }\end{array}$ \\
\hline
\end{tabular}

Продовження таблищі 1

\begin{tabular}{|c|l|l|}
\hline № & \multicolumn{1}{|c|}{ Критерії } & \multicolumn{1}{|c|}{ Показники } \\
\hline 6. & $\begin{array}{l}\text { Форма } \\
\text { отримання } \\
\text { контенту }\end{array}$ & Онлайн \\
\hline 7. & Цільова група & $\begin{array}{l}\text { Педагоги, які прагнуть підвищити } \\
\text { рівень ІК-компетентності або } \\
\text { розв'язати практичні проблеми }\end{array}$ \\
\hline 8. & Роль учасника & $\begin{array}{l}\text { Активний виконавець завдань, } \\
\text { який підтримує соціальну } \\
\text { комунікацію та взаємодію }\end{array}$ \\
\hline 9. & $\begin{array}{l}\text { Фокусування } \\
\text { навчання }\end{array}$ & $\begin{array}{l}\text { Фокусування на побудові } \\
\text { індивідуальної траєкторії розвитку }\end{array}$ \\
\hline
\end{tabular}

Заслуговують на увагу основні принципи мікронавчання: послідовності і систематичності, наочності, активності і самостійності, міцності засвоєння знань, залученості.

Принципи послідовності і систематичності відображаються в структурній лаконічності і регулярності подання змісту навчання та навчальних матеріалів.

Принцип наочності реалізується поданням мультимедійного навчального контенту, зокрема у відеоформаті.

Принцип залученості педагогів полягає у важливості зацікавленості педагогів в отриманні нових знань та втілюється через їх добровільну згоду навчатися.

Принципи активності і самостійності простежуються в умовах обов'язкового самостійного виконання завдань курсу, які можуть виконуватися як синхронно, так і асинхронно.

Принцип міцності засвоєння знань забезпечується якістю набутих знань і навичок, доступністю процесу навчання, отриманням дієвої оперативної допомоги і консультацій.

Зазначені принципи мікронавчання складають методичну основу онлайнового марафону. Мікронавчання IK-технологій педагогів в умовах онлайнового марафону полягає в організації і проведенні навчання на засадах онлайнових вебінарів тривалістю від 3 до 5 днів з обов'язковим виконанням невеликих за обсягом домашніх завдань та активної комунікації в тематичній групі соціальної мережі Facebook.

Учасниками такого заходу можуть бути вчителі закладів загальної середньої освіти, викладачі закладів професійної (професійно-технічної), фахової передвищої і вищої освіти. Навчання таких категорій учасників організовується в другу половину дня і триває не більше 2 годин. Основні 
процедури організації такого заходу представлено в табл. 2.

Табличя 2

Процедурна модель організації мікронавчання IKтехнологій педагогів в умовах онлайнового марафону

\begin{tabular}{|c|c|c|c|}
\hline \multicolumn{4}{|c|}{$\begin{array}{l}\text { Мета: розвиток ІК-компетентності педагогів на } \\
\text { засадах мікронавчання }\end{array}$} \\
\hline № & $\begin{array}{c}\text { Процедури } \\
\text { організації і } \\
\text { проведення } \\
\text { навчання }\end{array}$ & Особливості & $\begin{array}{c}\text { Сервіси для } \\
\text { реалізації } \\
\text { заходу }\end{array}$ \\
\hline 1. & $\begin{array}{l}\text { Розроблення } \\
\text { програми } \\
\text { навчання }\end{array}$ & $\begin{array}{l}\text { Курс триває три дні. } \\
\text { Кожний день } \\
\text { включає чотири } \\
\text { модулі тривалістю } \\
20 \text { хвилин }\end{array}$ & $\begin{array}{l}\text { Microsoft } \\
\text { Word }\end{array}$ \\
\hline 2. & $\begin{array}{l}\text { Запис на } \\
\text { навчання }\end{array}$ & Розроблення анкети & $\begin{array}{l}\text { Microsoft } \\
\text { Forms }\end{array}$ \\
\hline 3. & $\begin{array}{l}\text { Проведення } \\
\text { онлайнових } \\
\text { вебінарів }\end{array}$ & $\begin{array}{l}\text { Розроблення } \\
\text { графіка онлайнових } \\
\text { виступів, } \\
\text { визначення } \\
\text { тематики, } \\
\text { доповідачів на } \\
\text { основі анкети } \\
\text { доповідача }\end{array}$ & $\begin{array}{l}\text { Microsoft } \\
\text { Teams } \\
\text { Microsoft } \\
\text { Forms } \\
\text { Microsoft } \\
\text { Word }\end{array}$ \\
\hline 4. & $\begin{array}{l}\text { Виконання } \\
\text { завдань } \\
\text { учасниками } \\
\text { навчальної } \\
\text { програми }\end{array}$ & $\begin{array}{l}\text { Розроблення } \\
\text { одного невеликого } \\
\text { за обсягом } \\
\text { практичного } \\
\text { завдання за кожним } \\
\text { модулем. } \\
\text { Оголошення } \\
\text { домашніх завдань } \\
\text { наприкінці } \\
\text { навчального дня }\end{array}$ & $\begin{array}{l}\text { Microsoft } \\
\text { Teams } \\
\text { Сервіси } \\
\text { Office } 365 \\
\text { Спільнота } \\
\text { в мережі } \\
\text { Facebook } \\
\text { \#Cloud } \\
\text { services in } \\
\text { education }\end{array}$ \\
\hline 5. & $\begin{array}{l}\text { Зворотний } \\
\text { зв'язок }\end{array}$ & $\begin{array}{l}\text { Розміщення } \\
\text { учасниками } \\
\text { навчальної } \\
\text { програми } \\
\text { виконаних завдань } \\
\text { у тематичній } \\
\text { спільноті мережі } \\
\text { Facebook. } \\
\text { Здійснення } \\
\text { моніторингу } \\
\text { виконаних } \\
\text { учасниками } \\
\text { завдань. } \\
\text { Надання } \\
\text { організаторами } \\
\text { відповідей на } \\
\text { запитання }\end{array}$ & $\begin{array}{l}\text { Спільнота } \\
\text { в мережі } \\
\text { Facebook } \\
\text { \#Cloud } \\
\text { services in } \\
\text { education }\end{array}$ \\
\hline 6. & $\begin{array}{l}\text { Контроль } \\
\text { базових } \\
\text { знань }\end{array}$ & $\begin{array}{l}\text { Розроблення тесту } \\
\text { за тематикою курсу. } \\
\text { Кожен модуль } \\
\text { містить } 3 \text { ключові } \\
\text { питання }\end{array}$ & $\begin{array}{l}\text { Microsoft } \\
\text { Forms }\end{array}$ \\
\hline
\end{tabular}

Продовження таблиці 2

\begin{tabular}{|c|c|l|l|}
\hline № & $\begin{array}{c}\text { Процедури } \\
\text { організації і } \\
\text { проведення } \\
\text { навчання }\end{array}$ & \multicolumn{1}{|c|}{ Особливості } & $\begin{array}{c}\text { Сервіси для } \\
\text { реалізації } \\
\text { заходу }\end{array}$ \\
\hline 7. & $\begin{array}{l}\text { Отримання } \\
\text { сертифікату }\end{array}$ & $\begin{array}{l}\text { Надання відповідей } \\
\text { за тестом. } \\
\text { Завантаження } \\
\text { цифрового } \\
\text { сертифікату }\end{array}$ & $\begin{array}{l}\text { органит } \\
\text { оргатора }\end{array}$ \\
\hline
\end{tabular}

Завдання для учасників навчальної програми розроблено так, щоб створені ними об'єкти були об'єднані однією метою/ідеєю - створення хмаро орієнтованого навчального середовища для організації дистанційної та змішаної форм навчання учнів/студентів (табл. 3).

Табличя 3

Виконання завдань учасниками програми в процесі мікронавчання

\begin{tabular}{|c|c|c|}
\hline Термін & Завдання & Сервіси \\
\hline \multirow[t]{4}{*}{1 день } & $\begin{array}{l}\text { Створення цифрового } \\
\text { освітнього середовища }\end{array}$ & $\begin{array}{l}\text { Microsoft } \\
\text { Teams }\end{array}$ \\
\hline & $\begin{array}{l}\text { Створення віртуального класу/ } \\
\text { групи. Запрошення учнів до } \\
\text { класу/групи (код доступу) }\end{array}$ & $\begin{array}{l}\text { Microsoft } \\
\text { Teams }\end{array}$ \\
\hline & $\begin{array}{l}\text { Створення навчального } \\
\text { завдання (фрагмент) }\end{array}$ & $\begin{array}{l}\text { Microsoft } \\
\text { Teams }\end{array}$ \\
\hline & $\begin{array}{l}\text { Створення презентації до } \\
\text { уроку (фрагмент) }\end{array}$ & $\begin{array}{l}\text { Microsoft } \\
\text { Sway }\end{array}$ \\
\hline \multirow[t]{4}{*}{2 день } & $\begin{array}{l}\text { Створення опитувальника/ } \\
\text { тесту (фрагмент) }\end{array}$ & $\begin{array}{l}\text { Microsoft } \\
\text { Forms }\end{array}$ \\
\hline & Створення відеозвернення & FlipGrid \\
\hline & $\begin{array}{l}\text { Планування тематичного } \\
\text { вебінару }\end{array}$ & $\begin{array}{l}\text { Microsoft } \\
\text { Teams }\end{array}$ \\
\hline & $\begin{array}{l}\text { Інтегрування } 1 \text { сервісу в } \\
\text { цифрове освітнє середовище }\end{array}$ & $\begin{array}{l}\text { Math Solver / } \\
\text { GeoGebra }\end{array}$ \\
\hline \multirow[t]{3}{*}{3 день } & $\begin{array}{l}\text { Планування тематичного } \\
\text { конкурсу/олімпіади } \\
\text { (макет структури) }\end{array}$ & $\begin{array}{l}\text { Office } 365 \\
\text { Microsoft } \\
\text { Teams }\end{array}$ \\
\hline & $\begin{array}{l}\text { Інтегрування } 1 \text { сервісу } \\
\text { в цифрове освітнє } \\
\text { середовище - моніторинг } \\
\text { діяльності учнів за } \\
\text { дистанційною формою } \\
\text { навчання }\end{array}$ & Insights \\
\hline & $\begin{array}{l}\text { Створення цифрової } \\
\text { навчальної картки - нові } \\
\text { можливості та надбудови в } \\
\text { пакеті Microsoft Office }\end{array}$ & $\begin{array}{l}\text { Microsoft } \\
\text { Word, Excel, } \\
\text { PowerPoint } \\
\text { Book Creator }\end{array}$ \\
\hline
\end{tabular}


Продовження таблиці 3

\begin{tabular}{|l|l|l|}
\hline Термін & \multicolumn{1}{|c|}{ Завдання } & \multicolumn{1}{|c|}{ Сервіси } \\
\hline 3 день & $\begin{array}{l}\text { Проходження 1 навчального } \\
\text { курсу професійного розвитку } \\
\text { педагога. Отримання бейджу }\end{array}$ & $\begin{array}{l}\text { Мережа } \\
\text { «Партнерство } \\
\text { в навчанні» }\end{array}$ \\
\hline $\begin{array}{l}\text { Вільний } \\
\text { вибір }\end{array}$ & $\begin{array}{l}\text { Опитування. Отримання } \\
\text { сертифікату }\end{array}$ & $\begin{array}{l}\text { Microsoft } \\
\text { Forms }\end{array}$ \\
\hline
\end{tabular}

Процес навчання в онлайновому марафоні вибудовується з огляду на відповідність одного модулю одній темі, а кожен пост в соціальній мережі демонструє результат навчання на одному занятті. Подібна рамкова структура сприяє цілісності навчальної програми. Як зазначає А.П. Авраменко (2019), формати завдань варіюються залежно від мети конкретного заняття, утім становлять систему з повторюваних структурних модулів. До нових форматів завдань відносяться: мікровебінар, мікроаналіз, мікроштурм, мікросинтез, мікрокейс.

Онлайновий марафон з розвитку ІК-компетентностей проводився в Україні у квітні 2021 р. У ньому взяли участь 1200 педагогів з 24 областей України та м. Києва (рис. 2).

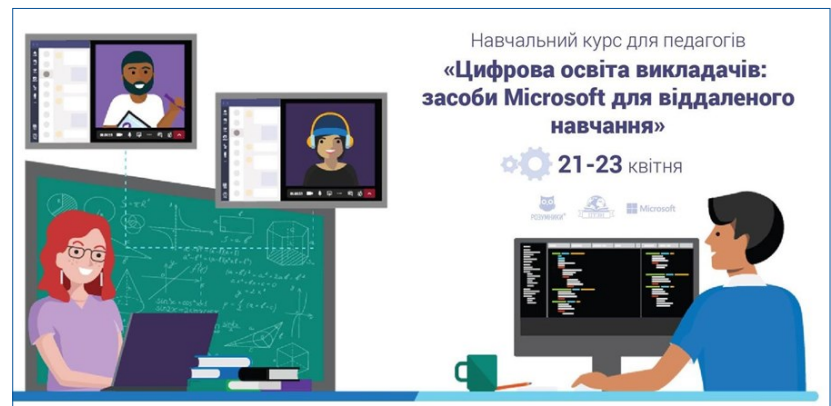

Рис. 2. Розміщення оголошення в соціальній мережі Facebook

Аналіз даних опитування засвідчує, що найбільш активними учасниками навчання були педагоги зі стажем 5-15 років - 60\%, вчителі середньої і старшої школи - $29 \%$. Відсоток правильних відповідей знаходився у діапазоні від $71 \%$ до 99 \%, що демонструє якість навчання.

Під час марафону педагогам надавалась онлайнова підтримка в мережі Facebook, зокрема здійснювався моніторинг запитань і надавались оперативні відповіді в чаті вебінару (рис. 3).

Загалом учасники навчальної програми оцінили її у 4,9 балів за п'ятибальною шкалою оцінювання, а свою вмотивованість впроваджувати отримані знання в практику - у 4,76 балів, що підтверджує якість та ефективність системи мікронавчання.

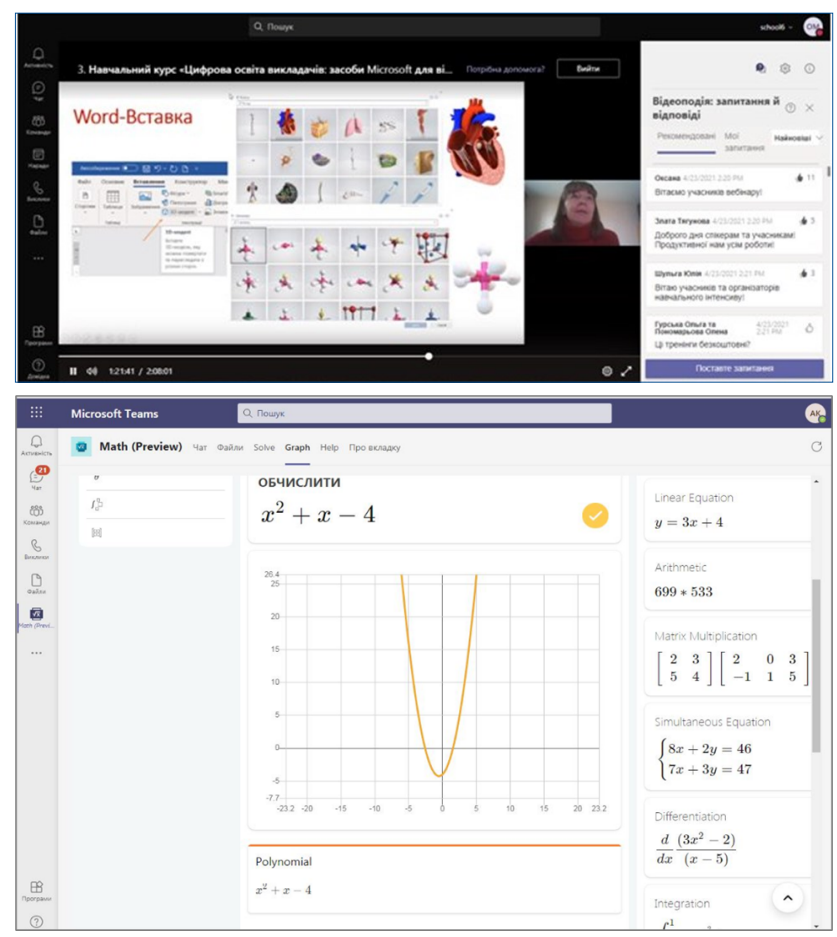

Рис. 3. Фрагменти онлайнового вебінару в середовищі Microsoft Teams

Отже, технологія мікронавчання $€$ синтезом мобільного та адаптивного навчання (Авраменко, 2019) й ефективним засобом впровадження як хмарних сервісів для організації змішаної і дистанційної форм навчання, так і різних новітніх цифрових технологій в освітню практику.

\section{СПИСОК ВИКОРИСТАНИХ ДЖЕРЕЛ}

Авраменко, А.П. (2019). Онлайн-марафон как модель развития профессиональной компетенции преподавателя иностранных языков в парадигме микрообучения. Педагогические науки, (4), 75-82. https:// cutt.ly/5bmENMu

Биков, В.Ю. (2019). Цифрова трансформація суспільства і розвиток комп'ютерно-технологічної платформи освіти і науки України. In В.Г. Кремень, О.І. Ляшенко (ред.), Інформачійно-цифровий освітній простір України: трансформачійні процеси і перспективи розвитку : матеріали методологічного семінару НАПН України (с. 20-26). Київ: ІІТЗН НАПН України. https://lib.iitta.gov.ua/718692/

Бугайчук, К.Л. (2017). Мікронавчання: поняття, особливості, переваги. In Дистанційне навчання cmapm із сьогодення в майбутнє : збірник науково-методичних праць III Всеукраїнської науковопрактичної конференції з міжнародною участю (с. 26). Харків: ХНУ ім. В.Н. Каразіна. https://cutt.ly/ UbmYI5U

Величко, В.Є., \& Федоренко, О.Г. (2020). Організація навчальної діяльності за технологією мікронавчання під час пандемії COVID-19. Технології електронного навчання, 4, 67-75. https://doi.org/10.31865/2709840002020222557

Інститут інформаційних технологій і засобів навчання НАПН України. (2021, 24 квітня). «Цифрова освіта 
викладачів: засоби Microsoft для віддаленого навчання». https://iitlt.gov.ua/info/news/sem-nari/ tsyfrova-osvita-vykladachiv-zasoby-microsoft-dlyaviddalenogo-navchannya3/

Литвинова, С. (2017). Хмаро орієнтоване навчальне середовище загальноосвітнього навчального закладу. In Proceedings of the 5th Workshop on Cloud Technologies in Education, CTE-2017 (pp. 7-12). http://ceur-ws.org/Vol-2168/paper2.pdf

Монахова, Г.А., Монахов, Д.Н., \& Прончев, Г.Б. (2020). Микрообучение как феномен цифровой трансформации образования. Образование и право, (6), 299304. https://doi.org/10.24411/2076-1503-2020-10645

Міністерство освіти і науки України. (2021, 16 квітня). 21-23 квітня вчителі зможуть пройти курс «Цифрова освіта викладачів: засоби Microsoft для віддаленого навчання». https://mon.gov.ua/ua/ events/21-23-kvitnya-vchiteli-zmozhut-projti-kurscifrova-osvita-vikladachiv-zasobi-microsoft-dlyaviddalenogo-navchannya

Національна академія педагогічних наук України. (2021, 27 квітня). ІІТЗН НАПН України: «Цифрова освіта викладачів: засоби Microsoft для віддаленого навчання». http://naps.gov.ua/ua/press/releases/2310/

Олійник, Н.Ю., \& Половін, Б.А. (2014). Персональне навчальне середовище як стратегія навчання в сучасному інформаційному суспільстві. Проблеми інженерно-педагогічної освіти, (45), 21-25. http:// nbuv.gov.ua/UJRN/Pipo_2014_45_5

Соловйов, В.М., Семеріков, С.О., \& Теплицький, І.О. (2009). Мікронавчання як основа мобільного навчання. In Матеріали міжнародної науковометодичної конферениії «Проблеми математичної освіти», ПМО-2009 (с. 196-197). Черкаси : Видавничий відділ чНУ ім. Б. Хмельницького. http://elibrary.kdpu.edu.ua/handle/0564/932
\#Cloud services in education. (n.d.). Обговорення [Facebook Group]. Facebook. https:// www.facebook.com/groups/1429370987315738

Buchem, I., \& Hamelmann, H. (2010). Microlearning: A Strategy for Ongoing Professional Development. elearning Papers, (21), 1-15. https:// www.researchgate.net/publication/341323117

European Commission. (2021). Micro-credentials broadening learning opportunities for lifelong learning and employability. In preparation. https:// ec.europa.eu/info/law/better-regulation/have-yoursay/initiatives/12858-Micro-credentials

Hug, T. (2010). Mobile Learning as 'Microlearning': Conceptual Considerations towards Enhancements of Didactic Thinking. International Journal of Mobile and Blended Learning, 2(4), 47-57. https:// doi.org/10.4018/jmbl.2010100104

LeewayHertz. (2021). Digital Transformation in Education Industry. https://www.leewayhertz.com/digitaltransformation-in-education/

Kokoulina O. (2020, May 27). Microlearning 101: Using a Little Learning to Grow Big Skills. Ispring. eLearning Basics. https://www.ispringsolutions.com/blog/whatis-microlearning

Pinchuk, O., Burov, O., \& Lytvynova, S. (2020). Learning as a Systemic Activity. In W. Karwowski, T. Ahram, S. Nazir (Eds), Advances in Human Factors in Training, Education, and Learning Sciences. AHFE 2019. Advances in Intelligent Systems and Computing, 963 (pp. 335-342). Springer, Cham. https:// doi.org/10.1007/978-3-030-20135-7_33

Sen, A.I. (2009). A Study on the Effectiveness of Peer Microteaching in a Teacher Education Program. Education and Science, 34(151), 165-174. https:// app.trdizin.gov.tr/publication/paper/detail/ T1RBMU56YzM

\title{
EDUCATORS' MICROLEARNING OF ICT VIA ONLINE MARATHON AS A PARADIGM OF EDUCATION DIGITAL TRANSFORMATION
}

\author{
Svitlana Lytvynova \\ DSc in Pedagogy, Senior Researcher, Deputy Director for Research, Institute of Information Technologies \\ and Learning Tools of the National Academy of Educational Sciences of Ukraine, Kyiv, Ukraine
}

Abstract. The paper defines and describes the components of education digital transformation (distance learning, videoconferencing, online learning, immersive technologies, smart classes, adaptive training, artificial intelligence, and chatbots). The process of introduction of microlearning as a growing need for short-term individual ICT training of educators is substantiated. The purpose of the roadmap "A European approach to micro-credentials for lifelong learning and employability" is described, which correlates with the large-scale introduction of microlearning technology. The main directions of studies are analyzed, and their results are taken into account when developing an online marathon program. The basic principles of the introduction of microlearning technology are determined, its advantages, disadvantages are grounded, and the main characteristics are defined (the form of learning, duration, content delivery, content types, content fragmentation, the form of content perception, the role of participants, focusing of learning). The procedural model of the organization of microlearning via online marathons is substantiated. The main types of micro-assignments and services for their implementation are described. The results of the online marathon, which involved 1200 educators who confirmed the effectiveness of their ICT-competence development under nonformal learning via microlearning technology are described.

Keywords: microlearning; ICT; teachers; online learning; marathon; the digital transformation of education.

Дата публікації: 7 травня 2021 р. 